\title{
PENGARUH SISTEM PENGENDALIANN INTERNAL, ASIMETRI INFORMASI, KESESUAIAN KOMPENSASI DAN KETAATAN ATURAN AKUNTANSI TERHADAP KECENDERUNGAN KECURANGAN AKUNTANSI (FRAUD) PADA ORGANISASI PERANGKAT DAERAH (OPD) KOTA DENPASAR
}

\author{
Dewa Ayu Anggreni Ekawati ${ }^{1}$, I.B. Made Putra Manuaba ${ }^{2}$, Ni L.P Ratna Wahyu Lestari ${ }^{3}$ \\ Program Studi Akuntansi \\ Fakultas Ekonomi dan Bisnis Universitas Warmadewa, Bali, Indonesia \\ Email : dewaayu.anggreni98@gmail.com
}

\begin{abstract}
ABSTRAK
Kecurangan akuntansi merupakan suatu yang menyangkut tindakan yang secara illegal bercirikan penipuan yang disengaja identik dengan korupsi, penyalah gunaan asset serta pertanyaan palsu. Penelitian ini berjudul "Pengaruh Sistem Pengendalian Internal, Asimetri Informasi, Kesesuaian Kompensasi dan Ketaatan Aturan Akuntansi Terhadap Kecenderungan Kecurangan Akuntansi (Fraud) Pada Organisasi Perangkat Daerah (OPD) Kota Denpasar", yang bertujuan untuk memaparkan hasil pengujian pengaruh masing-masing variabel yaitu sistem pengendalian internal, asimetri informasi, kesesuaian kompensasi dan ketaatan aturan akuntansi terhadap kecenderungan kecurangan akuntansi (fraud) pada OPD Kota Denpasar dengan menggunakan purposive sampling sebagai teknik pengumpulan sampel. Besar populasi yang digunakan merupakan seluruh pegawai dari 21 kantor pemerintahan di Kota Denpasar berjumlah 1.568 orang dengan sampel responden sebanyak 84 responden. Adapun teknik analisis yang dipakai yaitu metode analisis regresi linier berganda. Hasil dari penelitiian ini memaparkan bahwasanya variabel sistem pengendalian internal, kesesuaiian kompensasi dan ketaatan aturan akuntansi berpengaruh negatif, sedangkan variabel asimetri informasi berpengaruh positif terhadap fraud pada OPD Kota Denpasar.
\end{abstract}

Kata kunci: Pengendalian, Asimetri, Kompensasi, Aturan, Fraud

\begin{abstract}
Accounting fraud is something that involves actions that are illegally characterized by intentional fraud synonymous with corruption, misuse of assets and false questions. This study is entitled "The Influence of Internal Control Systems, Information Asymmetry, Compensation Compliance and Obedience of Accounting Rules to the Tendency of Accounting Fraud (Fraud) in Regional Apparatus Organizations (OPD) of Denpasar City",
\end{abstract}


which aims to describe the results of testing the effect of each variable, namely the control system internal, information asymmetry, compensation suitability and compliance with accounting rules for the tendency of accounting fraud (fraud) in the OPD Denpasar City using purposive sampling as a sample collection technique. The size of the population used was all employees of 21 government offices in Denpasar City totaling 1,568 people with a sample of 84 respondents. The analysis technique used is the method of multiple linear regression analysis. The results of this research explain that internal control system variables, compensation compliance and compliance with accounting rules negatively affect, while information asymmetry variables have a positive effect on fraud in OPD Denpasar City.

Keywords: Control, Asymmetry, Compensation, Rules, Fraud

\section{A. PENDAHULUAN}

Kecurangan akuntansi (fraud) merupakan suatu yang menyangkut tindakan yang secara illegal bercirikan penipuan yang disengaja seperti penyelewengan dari prosedur akuntansi yang semestinya dilaksanakan dalam suatu perusahaan, nantinya akan berdampak pada laporan keuangan yang dipaparkan oleh suatu entitas. Berikut ini fraud dalam 3 kelompok, antara lain; 1) Korupsi, 2) Penyalahgunaan aset, 3) Pernyataan palsu. Di Indonesia diperlukanlah pemerintahan yang baik untuk penyelenggaraan rancangan anggaran biaya serta program dan kegiatan pemerintah nantinya, maka dari itu OPD merupakan salah satu kunci pokok pengelolaan keuangan daerah/kota. Penelitian ini ditujukan untuk mengembangkan dan menguji variabel berdasarkan fenomena yang terjadi dilapangan, kesenjangan (research gap) berbeda pendapat dalam hasil penelitian terdahulu digunakan sebagai teori pendukung serta akan dikuatkan dengan responden di Organisasi Perangkat Daerah (OPD) Kota Denpasar.

\section{B. TINJAUAN PUSTAKA}

a. Teori Agensi

Suatu kondisi dimana adanya perbedaan pemahaman informasi yang diperoleh antara pemerintah dengan masyarakat yang nantinya menimbulkan asimetri informasi (Arfan Ikhsan, 2017:91). Peran pemerintah sangatlah penting dalam memberikan 
pertanggungjawabannya dalam menyikapi suatu konflik yang terjadi di masyarakat.

Maka dari itu, apabila pemerintah bekerja dengan baik, maka akan terciptanya kepercayaan masyarakat.

b. Teori Fraud Diamond

Dalam teori ini, terdapat empat aspek yang memungkinkan seseorang untuk melakukan fraud, antara lain; 1) Insentif merupakan dorongan untuk melakukan fraud dan menciptakan kebutuhan mendesak baginya untuk melakukan fraud, 2) Kesempatan merupakan tindakan yang timbul akibat kurangnya pengendalian internal yang diterapkan untuk mencegah dan mengawasi kecenderungan fraud dan lemahnya sanksi yang diberikan, 3) Pembeneran merupakan pola pikir pala pelaku fraud yang menjadi alasannya untuk membenarkan tindakannya, 4) Kapabilitas merupakan kemampuan yang diperlukan untuk melakukan fraud (Kurniawan, 2014:32).

c. Kecenderungan Kecurangan Akutansi (Fraud)

Fraud menurut IIA (Institute Of Internal Auditor) mengatakan bahwa fraud merupakan tindakan ilegal yang disertai dengan tindak penipuan, menyamarkan untuk mendapatkan keuntungan (uang, asset, jasa) yang bertujuan untuk menghindari kerugian bisnis atau pribadi (Kurniawan, 2014:09).

\section{d.Pengendalian Internal}

Suatu tindakan atas kebijakan dan prosedur yang harus ditaati pelaksanaan operasional dalam perusahaan agar memberikan keyakinan akan tercapainya tujuan sasaran dan harapan organisasi. Maka dengan ditingkatkannya prosedur dan pengawasan dalam suatu organisasi akan mencegah tindakan kecurangan dan dapat menumbulkan kerugian.

e. Asimetri Informasi

Suatu posisi dimana perusahaan sebagai pihak yang lebih menguasai informasi dibandingkan publik (Suwardjono, 2017:583). Keadaan dimana terjadi ketidak seimbangan informasi yang dimiliki oleh pemerintah dan masyarakat karena penyebaran informasi yang berbeda. Apabila tingkat asimetri informasi lebih tinggi yang terjadi dimasyarakat, akan menimbulkan tindakan illegal yang akan terjadi dan akan menimbulkan fraud. 


\section{f. Kesesuaian Kompensasi}

Suatu bentuk yang diterima oleh pekerja sebagai timbal balik atas kontribusi yang telah dikerahkan kepada perusahaan atau organisasi (Mulyadi, 2015:11). Kesesuaian serta kepuasan pada karyawan/pegawai/pekerja atas apa yang diberikan mencerminkan upaya organisasi dalam mewujudkan kesejahteraan karyawannya. Dengan kesesuaian upah yang diberikan, akan mengurangi tindak kecurangan yang terjadi akibat ketidakpuasan upah yang diterima.

g. Ketaataan Aturan Akuntansii

Adanya aturan dibuat sebagai pedoman dalam pelaksanaan agar tercapainya tujuan bersama yang telah ditetapkan. Maka, ketaatan terhadap aturan akuntansi selain mempermudah pemeriksaan juga mampu mengurangi tindakan illegal yang dapat merugikan perusahaan.

\section{METODE PENELITIAN}

Tempat penelitian ini dilaksanakan pada beberapa instansi di lingkungan pemerintah Kota Denpasar dengan objek yang melibatkan Kepala Dinas, Kasubag Keuangan, Bendahara dan Staf Subag Keuangan. Populasi dalam penelitiian inii adalah seluruh pegawai dari 21 instansi OPD di Kota Denpasar dengan jumlah 1.568 orang. Pengumpulan datanya menggunakan metode penyebaran kuisioner. Kuisioner ini nantinya akan dibuat dalam bentuk skala likert. Ujii instrumen yang digunakan yaitu validitas dan reliabilitas serta menggunakan uji asumsi klasiik, analisis regresi linier berganda dann uji kelayakan model.

\section{HASIL DAN PEMBAHASAN}

a. Uji Instrumen

Hasil dari uji validitas memaparkan keseluruhan indikator yang digunakan pada setiap variabel memiliki besar korelasi lebih besar dari 0,3 maka seluruh indikator variabel dikatakan valid. Serta hasil dari pengujian reliabilitas menyatakan bahwa setiap indikator variabel memiliki jumlah cronbach alpha lebih besar dari 0,70 maka seluruh instrumen variabel tersebut reliabel. 
b. Uji Asumsi Klasik

Berdasarkan hasil dari uji normalitas diperoleh bahwa koefisien Asymp. Sig $>$ 0,05 yaitu sebesar 0,75 dapat disimpulkan bahwa data tersebut menyebar secara normal. Berdasarkan hasil dari uji multikolonieritas diperoleh bahwa setiap variabel memiliki jumlah Variance Inflation Factor $<10$, dengan jumlah Tolerance $>10 \%$. Maka dari itu, tidak ada hubungan multikolonieritas dengan variabel independen(X). Hasil uji heteroskedastisitas menunjukan bahwa model regresi penelitian ini tidak mempunyai gangguan heteroskedastisitas maka model regresi ini layak untuk dipergunakan.

c. Uji Kelayakan Model

Nilai signifikansi sejumlah $0,000>0,05$ sehingga model regresi yang digunakan merupakan layak.

d. Analisis Regresi Linier Berganda

Berdasarkan dari hasil pengujian metode analisis regresi linier berganda pada Tabel 3 bentuk persamaan regresinya ialah $\mathrm{Y}=-0,309 \mathrm{X} 1+0,261 \mathrm{X} 2-0,354 \mathrm{X} 3-0,271 \mathrm{X} 4$. Maka dari hasil bentuk persamaan regresi linier berganda tersebut dapat dipaparkan, sebagai berikut: Maka besar $\beta 1$ memiliki arti apabila terjadi peningkatan pada sistem pengendalian internal (X1) sehingga diikuti dengan pengurangan kecenderungan kecurangan akuntansi (fraud) (Y). Nilai $\beta 2$ memiliki arti apabila terjadi peningkatan pada asimetri informasi (X2) maka akan diikuti dengan peningkatan kecenderungan kecurangan akuntansi (fraud) (Y). Nilai $\beta 3$ memiliki arti apabila terjadi peningkatan pada kesesuaian kompensasi (X3) diikuti dengan penurunan kecenderungan kecurangan akuntansi (fraud) (Y). Nilai $\beta 4$ memiliki arti apabila terjadi peningkatan pada ketaatan aturan akuntansi (X4) maka diikuti dengan penurunan kecenderungan kecurangan akuntansi (fraud) (Y). Variabel sistem pengendalian internal (X1) memiliki jumlah signifikansi sebesar 0,000 sehingga berpengaruh signifikan, asimetri informasi (X2) memiliki jumlah signifikansi 0,001 sehingga berpengaruh signifikan, kesesuaian kompensasi (X3) memiliki jumlah signifikansi 0,000 berpengaruh signifikan, ketaatan aturan 
akuntansi (X4) dengan jumlah signifikansi 0,002 sehingga berpengaruh signifikan terhadap fraud.

\section{E. PENUTUP}

\section{Simpulan}

Berdasarkan atas pemaparan uraian hasil pengujian analisis data serta pembahasan, sehingga dapat ditarik simpulan sebagai berikut memaparkan bahwa sistem pengendalian internal (X1) berpengaruh negatif, asimetri informasi (X2) berpengaruh positif, kesesuaian kompensasi (X3) berpengaruh negatif, ketaatan aturan akuntansi (X4) berpengaruh negatif terhadap fraud pada OPD Kota Denpasar.

\section{Saran}

Bagi peneliti selanjutnya nanti ada baiknya untuk lebih mengkaji dengan mengembangkan variabel yang lain sekiranya mampu mempengaruhi fraud. Selain itu bagi peneliti selanjutnya diharapkan untuk menambahkan kriteria dalam pengambilan sampel dan memperbanyak jumlah sampel yang digunakan agar memperoleh tingkat generalisasi yang lebih tinggi dengan memperluas wilayah penelitian.

\section{DAFTAR PUSTAKA}

Arfann Ikhsann Lubis. 2017. Akuntansi Keperilakuan, Salemba Empat, Jakarta.

Kurniawann Ardeno, 2014, Fraud di Sektor Publik dan Integritas Nasional, BPFE, Yogyakartaa.

Mulyadi, 20155, Manajemen Sumber Daya Manusia (MSDM), In Media, Bogor.

Suwardjono. 2017. Teori Akuntansi perekayasaan Pelaporan Keuangan, Edisi Tiga, BBPFE Yogyakarta, Yogyakarta. 